BANGLADESH J CHILD HEALTH 2011; VOL 35 (2): 53-58

\title{
Utility of A Single Widal Test in The Diagnosis of Typhoid Fever
}

\author{
ABM SHAHIDUL ALAM ${ }^{1}$, FAHIM AHMED RUPAM ${ }^{2}$, FARHANA CHAITI ${ }^{3}$
}

\begin{abstract}
:
Background \& objectives: The clinical diagnosis of typhoid fever is difficult, as the presenting symptoms are often diverse and similar to those observed with other febrile illnesses. The definitive diagnosis of typhoid fever requires the isolation of Salmonella typhi or paratyphi from the patient concerned. Since patients often receive antibiotics prior to a confirmatory diagnosis, there is uncertainty that bacteria can be isolated from the blood cultures. Besides this, the facilities for blood culture are not always available or feasible. All these limitations have made Widal test the most utilized diagnostic test for typhoid fever. Many studies have produced data which had cast serious doubts on the value of the Widal Test and thus reappraisal of the role of a single Widal test is needed.
\end{abstract}

Methods \& materials: This study was carried out to determine the changes in clinical pattern of enteric fever. A total of 153 children, aged 0 to 14 years, diagnosed as typhoid fever (either positive blood culture for Salmonella typhi or paratyphi) were induced in the study. Of them, 86 children were with a definitive diagnosis of typhoid or paratyphoid fever as indicated by the isolation of S. typhi or S. paratyphi from the blood and 17 had negative blood culture but were clinically suspected of having typhoid fever. The control group was comprised of 50 children with non-typhoidal fevers The Widal test was carried out using rapid slide agglutination method and its accuracy was assessed by comparing the findings with that obtained through blood culture.

Result: The mean age of the patients was $5.2 \pm 2.8$ years and the youngest and oldest patients were 0.7 and 14 years respectively and male to female ratio was roughly 1:1. Nearly one-quarter (24.6\%) of the patients had been suffering from the disease for $>10$ days and the mean duration of illness was $8.2 \pm 3.3$ days. Widal Test result showed that an ' $O$ ' agglutinin titer of cut-off value $e$ "1:40 gave a sensitivity of $87.2 \%$, a specificity of $47.1 \%$, a positive predictive value (PPV) of $89.2 \%$ and a negative predictive value (NPV) of $42.1 \%$. The sensitivity and NPV decreased with the increase in titer levels and were $56.9 \%$ and $31.5 \%$ at cut-off value of e" $1: 320$, while the specificity and PPV increased with the increase in titer levels from $47.1 \%$ and $89.2 \%$ respectively at a titer of e"1:40 to $100 \%$ at a titer of e" 1:320. The 'titer behaved in the same way as did the 'O' agglutinin titer. Similarly when $H$ ' agglutinin was used the sensitivity and NPV decreased from $65 \%$ and $31.7 \%$ at a titer of e"1:40 to only $25 \%$ and $20 \%$ respectively at a titer of $>1: 320$, while specificity and PPV increased from $76.4 \%$ and $81.1 \%$ at $>1: 40$ to $94.1 \%$ and $95.6 \%$ respectively at $e "$ 1:320. When either ' $O$ ' or ' $H$ ' antibody titer of e"1:160 was used, a good sensitivity (71\%), specificity (70.6\%) and PPV (92.4\%) resulted, though NPV decreased to $32.4 \%$.

Conclusion: The Widal test can be of diagnostic value when blood cultures are not available nor practically feasible.

Key words: Widal test, diagnostic accuracy and typhoid fever.

1. Chief Consultant \& Head, Department of Pediatrics, Central Police Hospital, Dhaka.

2. Asstt. Director, Central Hospital Ltd, Green Road, Dhaka.

3. Internee Doctor, BIRDEM Hospital, Dhaka.

Correspondence: Dr. ABM Shahidul Alam
Introduction:

Typhoid fever occurs in all parts of the world where there is substandard water supply and sanitation. It has almost been eliminated from developed countries 
because of sewage and water treatment facilities but remains a common disease and a major cause of morbidity and mortality in the third world countries. Exposure of the individual to contaminated food or water closely correlate with the risk for enteric fever ${ }^{1,2}$. Typhoid fever is a febrile illness of prolonged duration marked by step-ladder fever, dffuse abdominal pain, frontal headache, delirium, splenomegaly, hepatomegaly and many other systemic manifestations due to bacteremia and septicemia. However, with indiscriminate use of antibiotics multidrug resistant strains of Salmonella typhi are emerging with changing clinical pattern posing problem in diagnosis ${ }^{3}$.

The definitive diagnosis of typhoid fever requires the isolation of Salmonella typhi or paratyphi from the blood, feces, urine or other body fluids. In developing countries, facilities for isolation and culture are often not available especially in smaller hospitals, and diagnosis relies upon the clinical features of the disease and the detection of agglutinating antibodies to $S$. typhi and S. paratyphi by the Widal test. Many studies $^{4-8}$, however, have produced data which have casted serious doubts on the value of the Widal Test. Classically, a four fold rise of antibody in paired sera is considered diagnostic of typhoid fever ${ }^{9}$. However, paired sera are often difficult to obtain and specific chemotherapy has to be instituted on the basis of a single Widal test. In view of the doubts casted on the value of the Widal test, the present study was intended to reassess the utility of a single Widal test in the diagnosis of typhoid fever.

\section{Methods}

This cross-sectional study was carried out at Central Hospital Ltd., Dhaka over a period of 16 months from September 2008 to December 2009 on 153 children from 0 to 14 years of age after obtaining Ethical Clearance from the Central Hospital Ethical Committee. The study children were selected consecutively in the study. Of them, 86 children were with a definitive diagnosis of typhoid or paratyphoid fever as indicated by the isolation of S. typhi or $S$. paratyphi from the blood and 17 had negative blood culture but were clinically suspected of having typhoid fever, because of a two-fold rise of 'O' agglutinin titer and/or symptoms and signs mimiced with a classic pattern of typhoid fever. The control group was formed of cases of non-typhoidal febrile illness having negative blood culture for salmonella typhi or paratyphi. Fifty (50) children with non-typhoidal fever included patients of meningitis $(n=8)$, pneumonic consolidation $(n=$ $15)$, pulmonary tuberculosis $(n=3)$, pleural effusion $(n=4)$, pharyngitis $(n=9)$, urinary tract infection $(n=$ 11). The Widal test was carried out using rapid slide agglutination method. Data were analysed using SPSS (Statistical Package for Social Sciences) version 12. To assess the accuracy of the Widal test in detecting the presence or absence of typhoid fever sensitivity, specificity, positive and negative predictive values and diagnostic accuracy were calculated at each titer level.

\section{Result}

The mean age of 153 patients ( 86 with definitive typhoid fever, 17 with suspected typhoid fever and 50 with non-typhoidal febrile illness), was $5.2 \pm 2.8$ years and the youngest and oldest patients were 0.7 and 14 years respectively. Over half (54\%) of patients was male with male to female ratio being roughly $1: 1$. About $17 \%$ of patients had a history of suffering between $1-$ 5 days, $24.6 \%$ between $11-15$ days and $58.5 \%$ between $6-10$ days. The mean duration of illness was $8.2 \pm 3.3$ days and the minimum and maximum durations were 1 and 15 days respectively (Fig. 1). It is seen (from table I) that more than $97 \%$ of the definitive typhoid fever and $82.3 \%$ of the suspected typhoid fever cases had an 'O' agglutinin titer of 1:160 or $>1: 160$ as compared to only $2 \%$ cases of nontyphoid febrile illness ( $p<0.001)$. Similarly, $20.9 \%$ of culture-positive and $29.3 \%$ of suspected typhoid fever cases had an ' $\mathrm{H}$ ' agglutinin titer of equal to or more than 1:160 as opposed to only $4 \%$ of the non-typhoid febrile illness cases $(p=0.003)$ (Table II).

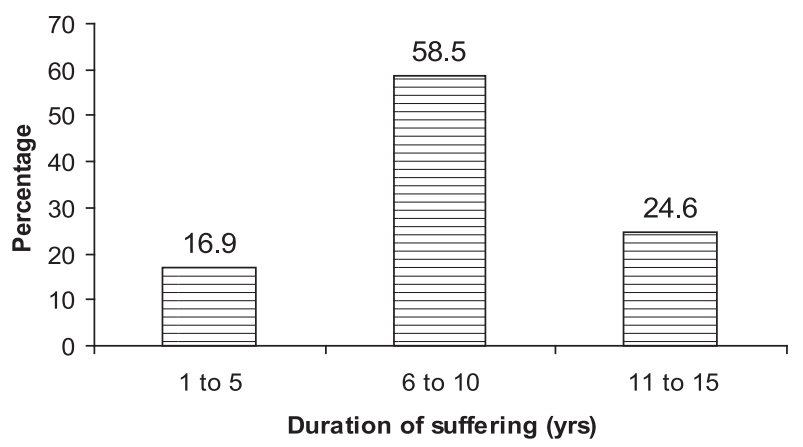

Fig.-1: Distribution of patients by duration of illness 
Table-I

Distribution of 'O' antibody titer among three groups of children:

\begin{tabular}{lcccc}
\hline \multirow{2}{*}{$\begin{array}{c}\text { 'O’ antibody } \\
\text { titers }\end{array}$} & $\begin{array}{c}\text { Definitive } \\
\text { typhoid fever } \\
(\mathrm{n}=86)\end{array}$ & $\begin{array}{c}\text { Guspected } \\
\text { typhoid fever } \\
(\mathrm{n}=17)\end{array}$ & $\begin{array}{c}\text { on-typhoid } \\
\text { febrile illness } \\
(\mathrm{n}=50)\end{array}$ & $\mathrm{p}$-value \\
\hline$<1: 40$ & $0(0.0)$ & $0(0.0)$ & $28(56.0)$ & \\
$>1: 40$ & $0(0.0)$ & $1(5.8)$ & $18(36.0)$ & $<0.001$ \\
$>1: 80$ (2-fold) & $2(2.3)$ & $2(11.9)$ & $3(6.0)$ & \\
$>1: 160$ (4-fold) & $48(55.8)$ & $9(52.9)$ & $1(2.0)$ & \\
$>1: 320$ (8-fold) & $36(41.9)$ & $5(29.4)$ & $0(0.0)$ & \\
\hline
\end{tabular}

Table II illustrates the accuracy of different Widal Test components in diagnosing typhoid fever. An ' $\mathrm{O}$ ' agglutinin titer of cut-off value $>1: 40$ gave a sensitivity of $87.2 \%$, a specificity of $47.1 \%$, a positive predictive value (PPV) of $89.2 \%$ and a negative predictive value (NPV) of $42.1 \%$. The sensitivity decreases with the increase in titer levels and was $56.9 \%$ at cut-off value of e" $1: 320$. Similarly NPV decreased from $42.1 \%$ at a titer of $>1: 40$ to $31.5 \%$ at a titer of $>1: 320$. The specificity increased with the increase in titer levels from $47.1 \%$ at a titer of $>1: 40$ to $100 \%$ at a titer of $>$ 1:320. PPV was also observed to increase with the increase in titer levels from $89.2 \%$ at a titer of $>1: 40$ to $100 \%$ at a titer of $>1: 320$. 'O' agglutinin titer gives a diagnostic accuracy of $80.1 \%$ at $>1: 40$ and $64 \%$ at $>1: 320$ (table III). The ' $\mathrm{H}$ ' agglutinin titer behaved in the same way as did the ' $O$ ' agglutinin titer. The sensitivity and NPV decreased from $65 \%$ and $31.7 \%$ to only $25 \%$ and $20 \%$ respectively, while specificity and PPV increased from $76.4 \%$ and $81.1 \%$ to $94.1 \%$ and $95.6 \%$ respectively at titers of $e^{\prime \prime} 1: 40$ and $e " 1: 320$ respectively (table IV). Using either 'O' or ' $\mathrm{H}$ ' antibody titer of 160 or more, we find a sensitivity of $61 / 86=$ $71 \%$, a specificity of $12 / 17=70.6 \%$ a PPV of $61 / 66=$ $92.4 \%$ and an NPV of $12 / 37=32.4 \%$ (table V).

Table-II

Distribution of ' $H$ ' antibody titer among three groups of children

\begin{tabular}{lcccc}
\hline 'H' antibody titers & \multicolumn{3}{c}{ Group } & p-value \\
\cline { 2 - 4 } & $\begin{array}{c}\text { Definitive } \\
\text { typhoid fever } \\
(\mathrm{n}=86)\end{array}$ & $\begin{array}{c}\text { Suspected } \\
\text { typhoid fever } \\
(\mathrm{n}=17)\end{array}$ & $\begin{array}{c}\text { Non-typhoid } \\
\text { febrile illness } \\
(\mathrm{n}=50)\end{array}$ & \\
\hline$<1: 40$ & $7(8.1)$ & $6(35.5)$ & $32(64.0)$ & \\
$>1: 40$ & $30(34.9)$ & $1(5.8)$ & $13(26.0)$ & 0.003 \\
$>1: 80$ (2-fold) & $31(36.1)$ & $5(29.4)$ & $3(6.0)$ & \\
$>1: 160$ (4-fold) & $13(15.1)$ & $3(17.6)$ & $2(4.0)$ & \\
$>1: 320$ (8-fold) & $5(5.8)$ & $2(11.7)$ & $0(0.0)$ & \\
\hline
\end{tabular}

Table-III

Components of accuracy for 'O' antibody at different titer levels:

\begin{tabular}{lccccc}
\hline $\begin{array}{l}\text { 'O' antibody at } \\
\text { different titers }\end{array}$ & $\begin{array}{c}\text { Sensitivity } \\
(\%)\end{array}$ & $\begin{array}{c}\text { Specificity } \\
(\%)\end{array}$ & $\begin{array}{c}\text { PPV } \\
(\%)\end{array}$ & $\begin{array}{c}\text { NPV } \\
(\%)\end{array}$ & $\begin{array}{c}\text { Diagnostic } \\
\text { Accuracy(\%) }\end{array}$ \\
\hline$>1: 40$ & 87.2 & 47.1 & 89.2 & 42.1 & 80.1 \\
$>1: 80$ (2-fold) & 79.1 & 64.7 & 91.9 & 37.9 & 76.7 \\
$>1: 160$ (4-fold) & 67.4 & 88.2 & 96.6 & 34.9 & 70.8 \\
$>1: 320$ (8-fold) & 56.9 & 100.0 & 100.0 & 31.5 & 64.0 \\
\hline
\end{tabular}


Table-IV

Components of accuracy of ' $H$ ' antibody at cut-off

\begin{tabular}{|c|c|c|c|c|c|}
\hline \multirow{2}{*}{$\begin{array}{l}\text { 'H' antibody at } \\
\text { different titers }\end{array}$} & \multicolumn{5}{|c|}{ Components of accuracy } \\
\hline & $\begin{array}{c}\text { Sensitivity } \\
(\%)\end{array}$ & $\begin{array}{c}\text { Specificity } \\
(\%)\end{array}$ & $\begin{array}{l}\text { PPV } \\
(\%)\end{array}$ & $\begin{array}{l}\text { NPV } \\
(\%)\end{array}$ & $\begin{array}{c}\text { Diagnostic } \\
\text { Accuracy(\%) }\end{array}$ \\
\hline$>1: 40$ & 65.1 & 76.4 & 81.1 & 31.7 & 80.2 \\
\hline > 1:80 (2-fold) & 41.8 & 82.3 & 92.3 & 21.8 & 58.1 \\
\hline$>1: 160$ (4-fold) & 32.5 & 88.2 & 93.3 & 20.5 & 50.0 \\
\hline$>1: 320$ (8-fold) & 25.6 & 94.1 & 95.6 & 20.0 & 44.1 \\
\hline
\end{tabular}

Table-V

Components of accuracy of either 'O' ' $H$ ' antibody at cut-off

\begin{tabular}{lccc}
\hline $\begin{array}{l}\text { Either 'O' or 'H' } \\
\text { antibody titer }\end{array}$ & \multicolumn{2}{c}{ Blood culture } & Total \\
\hline$>1: 160$ & Positive & Negative & \\
\hline $1: 160$ & 25 & 5 & 66 \\
\hline Total & 86 & 12 & 37 \\
\hline
\end{tabular}

\section{Discussion}

The present study was done to assess the role of a single Widal test in the diagnosis of typhoid fever. Our study demonstrated that an ' $\mathrm{O}$ ' agglutinin titer of $1: 160$ had a sensitivity of $67.4 \%$, a specificity of $88.2 \%$, a positive predictive value of $96.6 \%$, a negative predictive value of $34.9 \%$ and the overall accuracy of more than $70 \%$. This titer had a higher specificity and PPV but lower sensitivity and nearly comparable NPV as compared with a titer of 1:80. An 'H' agglutinin titer of $1: 160$ had a sensitivity of $32.5 \%$, a specificity of $88.2 \%$, a positive predictive value of $93.3 \%$, a negative predictive value of $20.5 \%$ and an accuracy of $50 \%$. This titer had an almost similar PPV and NPV when compared with a titer of $1: 80$, but it had a higher specificity (88.2\%) than that with titer of $1: 80(82.3 \%)$. These findings thus suggest that, although an ' $\mathrm{O}$ ' and an ' $\mathrm{H}$ ' agglutinin titer of 1:80 are indicative of typhoid fever, a titer of 1:160 should be considered of greater significance, because of its greater ability to rule out those who do not have the disease (specificity) and higher yield of true positive cases (PPV). Kulkarni and Rego ${ }^{10}$ held an almost similar view for ' $\mathrm{H}$ ' agglutinin. They reported that an ' $\mathrm{H}$ ' agglutinin of 1:160 titer had a negligibly lower specificity when compared with a titer of 1:80 (97\% vs. $98 \%$ ) but it had a higher positive predictive value than the latter one $(90 \%$ vs.
$84 \%$ ) which led them to hold the opinion that although an ' $\mathrm{H}$ ' agglutinin titer of 1:80 was suggestive, a titer of $1: 160$ was of greater significance.

Therefore, the Widal test can be helpful in the laboratory diagnosis of typhoid fever if interpreted with care. In order to use the Widal test effectively, each country should find the appropriate titer with which to diagnose typhoid fever. There have been numerous reports on the single Widal test but no consensus as to its diagnostic value in regions in which typhoid is endemic ${ }^{11-18}$. In our study, using either ' $\mathrm{O}$ ' or ' $\mathrm{H}$ ' antibody titer of $1: 160$, a modest sensitivity $(71 \%)$, specificity $(70.6 \%)$ and PPV (92.4\%) resulted, although the NPV (32.4\%) was much lower. Based on the above analysis, 'O' or 'H' titers when considered together of greater than or equal to $1: 160$ could be indicative of typhoid fever.

In endemic areas a substantial proportion of healthy population exhibit seropositivity against ' $\mathrm{O}$ ' and ' $\mathrm{H}$ ' antigen for Salmonella typhi or paratyphi. In a seroprevalence study for ' $\mathrm{O}$ ' and $\mathrm{H}$ antibodies against Salmonella typhi or paratyphi (by slide agglutination test) conducted by Turkish Ministry of Health, demonstrated that $25 \%$ of healthy adults were seropositive for ' $\mathrm{O}$ ' and $\mathrm{H}$ antibodies. ${ }^{19}$ In a study from Malaysia, $61 \%$ of healthy adults were seropositive against the $\mathrm{H}$ antigen and $6 \%$ were seropositive against $\mathrm{O}$ antigen ${ }^{20}$. On the other hand, in a retrospective study from Holland, the rate of seropositivity obtained when using the Widal test was found to be $1 \%{ }^{21}$. In a recent study from Vietnam, the O-agglutinin titer of $>100$ was found in $83 \%$ of the blood culture-positive typhoid fever cases, and the $\mathrm{H}$-agglutinin titer of e"100 in $67 \%$ cases. With a cutoff titer of e"200 for $O$ agglutinin or e" 100 for $\mathrm{H}$ agglutinin, the Widal test would diagnose correctly $74 \%$ of the culture-positive cases of typhoid fever. However, the test yielded 14\% 
false-positive and $10 \%$ false-negative results 22 . One of the reasons for these high rates of seropositivity against serotype typhi is the widespread presence of salmonella infections in the community. The other factors for the seroepidemiologic data are the crossreactivity of serotype typhi antigens with other salmonella infections and the longevity of these antibodies in the serum ${ }^{19}$.

The diagnosis of typhoid fever on clinical grounds is difficult, as the presenting symptoms are diverse and similar to those observed with other febrile illnesses. The definitive diagnosis of typhoid fever requires the isolation of Salmonella typhi or paratyphi from the patient. Bacteria can be isolated from blood in 73 to $97 \%$ of cases before antibiotic use ${ }^{23}$. However, since patients often receive antibiotics prior to a medical diagnosis, bacteria can be isolated from the blood cultures in only 40 to $60 \%$ of the cases ${ }^{24-26}$. Besides this, the unavailability of microbiologic facilities and the long waiting time for culture results ( 7 to 10 days) have been identified as reasons for the preference for the Widal test.

From the present study, it has also been evident that over $95 \%$ of the culture-positive cases exhibits an ' $O$ ' agglutinin titer of 1:160 or more on Widal Test. However, a substantial proportion of clinically suspected culturenegative cases (over $80 \%$ ) also demonstrates a 4 or $>4$-fold rise of ' $\mathrm{O}$ ' agglutinin titer. The reason of such phenomenon is that many cases of typhoid fever before being conclusively diagnosed are treated with antibiotics (either adequately or inadequately) which cause disappearance of bacteria from the peripheral blood and hence a negative blood culture result. But if a case of febrile illness is a case of typhoid fever and passes at least 7 days, the chance of a four-fold rise of ' $O$ ' agglutinin on Widal test is quite high. So any case of febrile illness, on clinical ground, if suspected of having typhoid fever and Widal test demonstrates a four-fold rise of 'O' agglutinin, he/she should be treated with an appropriate antibiotic for adequate duration, particularly where blood-culture facility is not accessible or available.

In conclusion, the Widal test is an easy, inexpensive, and relatively noninvasive test that can be of diagnostic value in situations where blood cultures are not available or feasible. But the results must be interpreted cautiously, as negative results do not exclude typhoid fever and positive results do not always go in favour. It is also to be considered whether the test was performed during acute-phase or during convalescent, as the test gives most-reliable results with high specificity, sensitivity, PPV, and NPV if conducted during convalescence. If 'O' or ' $\mathrm{H}$ ' titer has to be used in isolation (singly) for interpretation of result, 'O' should be preferred to ' $\mathrm{H}$ ' for its higher sensitivity and NPV at titer of 1:160. However, 'O' or ' $H$ ' titers of 1:160 if considered together, it could be indicative of typhoid fever but its low specificity may include some other febrile cases as typhoid fever.

\section{References:}

1. Sur D, Ali M, Lorenz von S, Manna B, Deen JL, Acosta CJ, et al. Comparisons of predictors for typhoid and paratyphoid fever in Kolkata, India. BMC Public Health 2007; 7: 289.

2. Chowta MN, Chowta NK. Study of clinical profile and antibiotic response in typhoid fever. Indian J Med Microbial 2005; 23(2): 125-7.

3. Hanon A. Changing pattern of S.typhi isolates in Pakistan and their unchanged response to ofloxacin. Int J Exper Clin Chemother 1991; 4: 225-9.

4. Schroeder SA. Interpretation of serologic tests for typhoid fever. JAMA 1968; 206(4): 839-40.

5. Sen A, Saxena SN. Critical assessment of the conventional Widal test in diagnosis of typhoid fever. Indian J Med Res 1969; 57(10): 1813-9.

6. Reynolds DW, Carpenter L, Simon WH. Diagnostic specificity of Widal's reactionfor typhoid fever. JAMA 1970, 204(12): 2192-3.

7. Wicks ACB, Holmes GS, Davidson L. Endemic typhoid fever-A diagnostic pitfall. Q J Med 1971; 40 (159): 341-54.

8. Anonymous. Typhoid and its serology. Br Med J 1978; 1(6117): 389-90.

9. Parker MT. Enteric infection: Typhoid and para typhoid fever. In: Wilson GS, Miles AS, Parker MT. Topley and Wilson's Principles of Bacteriology, Virology and Immunity, Vol III, 7th edn., London, Edward Arnold Publishers Limited, 1984. P. 843-9.

10. Kulkarni ML and Rego SJ. Value of single widal test in the diagnosis of typhoid fever. Inidian Ped 1994; 31: 1373-7.

11. Abraham GB, Teklu M, Gedebu GH, Selassie, Azene G. Diagnostic value of the Widal test. Trop Geogr Med 1981; 33(4): 329-33. 
12. Bhutta ZA and N. Mansurali. Rapid serologic diagnosis of pediatric typhoid fever in an endemic area: a prospective comparative evaluation of two dot-enzyme immunoassays and the Widal test. Am. J. Trop Med Hyg 1999; 61(4): 654-7.

13. House DJ, Wain VA, Ho TT, Diep NT, Chinh PV, Bay $\mathrm{H}$ et al. Serology of typhoid fever in an area of endemicity and its relevance to diagnosis. $\mathrm{J}$ Clin Microbiol 2001; 39(3):1002-7.

14. Mohammed IJO, Chikwemm, Gashau W. Determination by Widal agglutination of the baseline titre for the diagnosis of typhoid fever in two Nigerian states. Scand. J. Immunol 1992; Suppl 11:153-6.

15. Olopoenia LA, King AL. Widal agglutination test - 100 years later: still plague controversy. Postgrad. Med. J 2000; 76(892): 80-4. [PubMed]

16. Pang T, Puthucheary SD. Significance and value of the Widal test in the diagnosis of typhoid fever in the endemic area. J Clin Pathol 1983; 36(4): 471-8.

17. Saha SK, Ruhulamin M, Hanif M, Islam M, Khan A. Interpretation of the Widal test in the diagnosis of typhoid fever in Bangladeshi children. Ann Trop Paediatr 1996;16(1):75-8. [PubMed]

18. Senewiratne B, Senewiratne K. Reassessment of the Widal test in the diagnosis of typhoid. Gastroenterology 1997; 73(2): 233-6.

19. Republic of Turkey Ministry of Health.. Health Statistics. Republic of Turkey, Ministry of Health. Ankara, Turkey 1995.
20. Shukla S, Patel B, Chitnis DS. 100 years of Widal test and its reappraisal in an endemic area. Indian Med Res 1997;105:53-7.

21. Koeleman, JG, Rogensburg F, Katwijk D, Maclaren DM. Retrospective study to determine the diagnostic value of the Widal test in a nonendemic country. Eur J Clin Microbiol Infect Dis 1992;11(2):167-70. [PubMed]

22. Parry CM, Nguyen TTH, Diep TS. Value of a single-tube Widal test in diagnosis of typhoid fever in Vietnam. J Clin Microbiol 1999; 37(9): 2882-6. [PubMed]

23. Pearson RD, Guerrant RL. Enteric fever and other causes of abdominal symptoms with fever. In: Mandell GL, Bennett JE, Dolin R.(editors), Principles and practice of infectious diseases, $5^{\text {th }}$ ed. Churchill Livingstone, New York, 2000; p. $1136-50$.

24. Buke MG, Karakartal C, Gunhan D, Yuce K, Ozkan F. Ege Universitesi Infeksiyon Hastaliklari Kliniginde son 10 yilda saptanan tifo ve paratifo olgulari. Infeksiyon Dergisi 1987; 1: 231-6.

25. Kalayci C, Karacadag S, Kansu E.. Typhoid fever - a report of 90 cases. Infeksiyon Dergisi 1987; 3: 89-91.

26. Willke ATH, Sozen K, Gultan H, Kurt, Balik I. Tifo: 100 hastanin klinik, laboratuvar ve tedavi yonunden degerlendirilmesi. Ankara Tip Bulteni 1988;10:53-62. 